\title{
Macrofaunal community inside and outside of the Darwin Mounds Special Area of Conservation, NE Atlantic
}

\author{
N. Serpetti ${ }^{1,2}$, E. Gontikaki ${ }^{1}$, B. E. Narayanaswamy ${ }^{2}$, and U. Witte ${ }^{1}$ \\ ${ }^{1}$ Oceanlab, Institute of Biological and Environmental Sciences, University of Aberdeen, Aberdeen, AB41 6AA, UK \\ ${ }^{2}$ Scottish Association for Marine Science, Scottish Marine Institute, Oban, Argyll, PA37 1QA, UK
}

Correspondence to: N. Serpetti (natalia.serpetti@sams.ac.uk)

Received: 13 November 2012 - Published in Biogeosciences Discuss.: 29 November 2012

Revised: 3 May 2013 - Accepted: 11 May 2013 - Published: 5 June 2013

\begin{abstract}
Spatial distribution and patchiness of deep sea macrofaunal communities were studied from samples collected in the Rockall Trough, NE Atlantic. In June 2011, two areas, located outside and within the Darwin Mound Special Area of Conservation (SAC), were sampled. Three megacores were deployed in each area at approximately $900 \mathrm{~m}$ depth. The two areas, $\sim 18 \mathrm{~km}$ apart, did not differ in terms of sediment organic matter and percentage of mud content, but small significant differences were found in sediment median grain size and depth. Macrofaunal communities were found to differ significantly, with the difference mostly driven by changes in the abundance of polychaetes, crustaceans and nematodes whilst no significant differences were seen for the other phyla. Whereas overall macrofaunal abundance was higher outside the SAC compared to within, this pattern varies considerably between phyla. Diversity indices showed no significant differences between protected and unprotected sites. Deep-water trawling regularly take place outside the Darwin Mounds SAC whilst the area inside the SAC has been closed to bottom trawling since 2004, and the above distribution patterns are discussed in the context of both environmental and anthropogenic causes.
\end{abstract}

\section{Introduction}

Marine sediments are a major reservoir in the global carbon (C) cycle, and the cycling and burial of organic matter (OM) in marine sediments are key terms in the global $\mathrm{C}, \mathrm{N}$ and $\mathrm{P}$ cycles, linked to ocean nutrient budgets and productivity, and to climate. Although the bathyal continental margins constitute only $7 \%$ of the surface area of the oceans, approximately
$30 \%$ of all organic matter remineralisation, and thus nutrient recycling, occurs here (Middelburg et al., 1997). At the same time, the biodiversity of continental margin sediments is remarkably highly diverse, and is hypothesised to be a source of biodiversity for both the shallow continental shelves and the deeper ocean basins (Danovaro et al., 2008). The macrofaunal organisms that live within these sediments are known to be ecosystem engineers that, via their feeding activities and burrow structures, significantly alter the habitat structure, geochemical setting and food supply for other organisms. In many deep-sea systems, macrofauna are of primary importance in the early stages of organic matter (OM) diagenesis and recycling (e.g. Witte et al., 2003; Hunter et al., 2013). Echiurans, polychaetes and sipunculans, in particular, have been found to be keystone species that through their feeding and foraging activities supply deeper living micro- and macro-organisms with labile, easily degradable organic matter (Levin et al., 1999). Thus, the biodiversity and activity of seafloor macrofaunal communities and the cycling of OM and regeneration of nutrients on the seafloor are intimately linked. In addition, the benthic communities that live on and within the sediments of the continental margins provide important habitat and food resources (direct or indirect) for demersal fish.

While there are several studies showing clear bathymetric shifts and large-scale spatial distribution patterns (thousands of kilometres) of faunal communities (WlodarskaKowalczuk et al., 2004; Rex et al., 2006), much less attention has been given to the small-scale horizontal patterns (metres to a few kilometres) (Stuart et al., 2003; Budaeva et al., 2008). Previous studies of single species patchiness showed a dominance of random dispersion (Gage, 1975); 
small-scale horizontal patterns tend to be more uniform than at a larger scale. However heavily disturbed shallow water sediments can show high macrofaunal community heterogeneity (Kendall and Widdicombe, 1999).

Diversity patterns at different spatial scales can be affected by various factors (Whittaker, 1960). Climate processes, phylogenetic relationships and historical events tend to have a greater impact at larger spatial scales, whilst at small scales, competition, predation and dispersal capability could play an important role in determining horizontal patterns. Sediment organic matter content, grain size distribution and depth often represent the main factors that can determine macrofaunal community shifts in structure and abundance among sites between these two spatial scale extremes (Ellingsen, 2002). Natural and artificial disturbances can also determine smallscale community changes by increasing habitat complexity and heterogeneity (Balata et al., 2007; Levin et al., 2010).

Continental margin habitats are being increasingly altered by human activities, and the consequences of anthropogenic impacts on benthic biodiversity and ecosystem functioning in the deep sea are almost completely unknown (Levin and Dayton, 2009; Levin et al., 2010). Trawling disturbs benthic communities both physically and biologically, causing the resuspension and subsequent relocation via lateral transport of surficial sediments (Martin et al., 2008; Puig et al., 2012) and eliminating the most vulnerable organisms (Clark and Rowden, 2009). Several studies suggest that chronically disturbed communities are dominated by opportunistic species (de Juan et al., 2007), which may remove important food sources for commercially important fish, reduce biodiversity (Kaiser and Spencer, 1996; Duineveld et al., 2007; Clark and Rowden, 2009; de Juan et al., 2011) and have strong implications for biogeochemical processes such as nutrient regeneration (Puig et al., 2012). However, there have been relatively few studies investigating the impact and effects of trawling in the deep sea (Clark and Rowden, 2009), and there are even fewer studies which assess the macrofaunal community (Duineveld et al., 2007), or recovery times of benthic infaunal communities after intensive trawling.

Marine protected areas and special areas of conservation are generally created to protect specific targets, e.g. fish stocks, coral species, and peculiar geomorphological structures such as seamounts and hydrothermal vents. Although there is an expectation that regulating human activities in these areas will protect faunal biodiversity and abundance, we are far from understanding the efficiency of these closures, particularly on an ecosystem level.

The Darwin Mounds are situated in the north-east section of the Rockall Trough, $\sim 180 \mathrm{~km}$ to the north-west of Scotland, and were first discovered in 1998 (Bett, 2001). The mounds are found at a depth range of 900-1060 m (Masson et al., 2003), cover an area of about $1500 \mathrm{~km}^{2}$ and each mound is approximately $5 \mathrm{~m}$ high and $100 \mathrm{~m}$ in diameter (Bett, 2001). The Darwin Mounds are thought to be quite unique as they have "tail-like" formations associated with each mound. The sandy substrate of the mounds has been colonised by corals, including high numbers of Lophelia pertusa and Madrepora oculata (Gubbay et al., 2002). The mounds are also colonised by a diverse group of suspension feeders as well as infauna; some of the more unusual fauna include the large fragile xenophyophore Syringammina fragilissima (Masson et al., 2003; Van Gaever et al., 2004). Increasing evidence of destruction from bottom trawling and concerns regarding the damage from potential hydrocarbon exploration (Wheeler et al., 2005) eventually led to the Darwin Mounds being designated by the European Council in 2004 as the first offshore SAC in the United Kingdom. A total area of $1300 \mathrm{~km}^{2}$ is now permanently closed to bottom trawling (European Council, 2004) but not yet to pelagic trawling.

Here, we investigate small-scale spatial patterns of the sediment macrofauna in two areas inside and outside the Darwin Mounds SAC in an attempt to evaluate potential differences in community structure and their potential drivers.

\section{Material and methods}

\subsection{Study site and sample collection}

Sediment samples were collected using the NOC megacorer (i.d. of cores: $10 \mathrm{~cm}$ ) from two areas, inside and outside the Darwin Mounds SAC, during the RRS James Cook cruise 060 in May-June 2011. To ensure comparability, the stations sampled inside the SAC were outwith of the mounds themselves, and associated coral colonies as those outside the SAC. The stations outside the SAC were situated to the southeast of the Darwin Mounds. The distance between the two areas was $\sim 18 \mathrm{~km}$, and the maximum distance between replicates for both inside and outside SAC stations ranged from $0.7-1.3 \mathrm{~km}$. In total, 48 megacorer barrels were taken at six stations at a depth of $\sim 800 \mathrm{~m}$ (Table 1, Fig. 1). All cores were characterised by a top layer of up to $10 \mathrm{~cm}$ of sandy mud overlying glacial mud (as seen by Masson et al., 2003). The cores were sliced into $0-5 \mathrm{~cm}$ and $5-10 \mathrm{~cm}$ depth horizons. The fauna were elutriated through a $250 \mu \mathrm{m}$ mesh sieve and the resultant residue preserved in $10 \%$ formalin solution. A subsample of $10-20 \mathrm{~mL}$ was taken from one additional core per deployment and frozen at $-20^{\circ} \mathrm{C}$ for total organic carbon (TOC), total nitrogen (TN) and grain size analysis. The macrofauna were sorted in the laboratory, identified to the lowest possible taxonomic level (mainly putative species; see Supplement) and preserved in ethanol. We analysed all the taxa retained on a $250 \mu \mathrm{m}$ mesh including nematodes and copepods. However, with these two taxa, the specimens were not identified to species level and in the diversity calculations were used as a single entity. Pelagic taxonomic identities such as Cladocera branchiopods, Calanoida and Cyclopoida copepods and mysids were excluded from the analysis. 
Table 1. List of sampling stations inside and outside the Darwin Mound SAC.

\begin{tabular}{ccccc}
\hline Station & Latitude & Longitude & Depth & Location \\
\hline 107 & $59^{\circ} 47.724 \mathrm{~N}$ & $07^{\circ} 34.043 \mathrm{~W}$ & 815 & inside SAC \\
108 & $59^{\circ} 47.364 \mathrm{~N}$ & $07^{\circ} 34.147 \mathrm{~W}$ & 816 & inside SAC \\
112 & $59^{\circ} 47.582 \mathrm{~N}$ & $07^{\circ} 33.538 \mathrm{~W}$ & 823 & inside SAC \\
113 & $59^{\circ} 41.905 \mathrm{~N}$ & $07^{\circ} 47.462 \mathrm{~W}$ & 773 & outside SAC \\
114 & $59^{\circ} 41.907 \mathrm{~N}$ & $07^{\circ} 48.071 \mathrm{~W}$ & 771 & outside SAC \\
115 & $59^{\circ} 41.894 \mathrm{~N}$ & $07^{\circ} 48.844 \mathrm{~W}$ & 769 & outside SAC \\
\hline
\end{tabular}

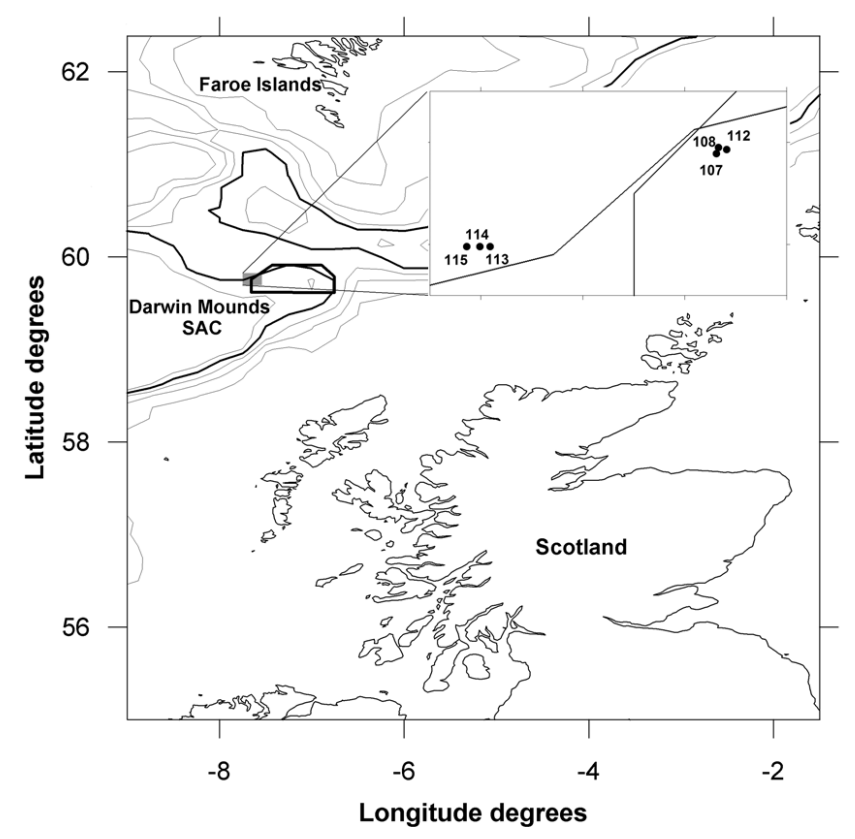

Fig. 1. Study area showing the sampling locations inside (stations 107-108 and 112) and outside (stations 113-114 and 115) the SAC. The SAC area and the $800 \mathrm{~m}$ contour are shown in bold.

\subsection{Statistical analysis}

Analysis of the macrofaunal communities was undertaken using PRIMER V6 (Clarke and Warwick 2001). Univariate analysis was carried out on sediment properties (TOC, $\mathrm{TN}$, median grain size and mud content) and on macrofaunal community indices (including Margalef's species richness $(d)$, Shannon's diversity $\left(H^{\prime}\right)$, Pielou's evenness $\left(J^{\prime}\right)$ and Simpson's dominance $\left(1-\lambda^{\prime}\right)$; Clarke and Warwick, 2001). An ANOVA test was used to evaluate the significant differences between samples collected inside and outside the SAC. Multivariate analysis was undertaken using cluster analysis and non-metric multi-dimensional scaling (MDS). In order to weight the importance of dominant and rare species, we applied a square-root transformation of the species abundance data (Clarke and Warwick, 2001). A similarity profile test (SIMPROF) was used to determine if there were significant differences in the internal macrofaunal multivariate struc- ture between all the samples. A similarity percentage test (SIMPER) was carried out to evaluate the role of individual species in contributing to the group separations (Clarke and Warwick, 2001; Clarke and Gorley, 2006).

\section{Results}

A total of 183 different taxonomic identities were collected from the six stations that were sampled. The macrofaunal community was dominated by polychaetes (72 species) followed by crustaceans (56 species) and molluscs ( 37 species). The polychaete community was dominated by spionids, cirratulids, paraonids, glycerids, hesionids and polynoids, three detritivore and three carnivorous families respectively. Among the crustacean community, large specimens of the amphipod Haploops setosa were dominant outside the SAC stations together with small specimens of harpacticoid copepods and ostracods. One species of Solenogastres was dominant among the mollusc taxon together with the bivalve Yoldiella $\mathrm{sp}_{-} 1$ and the scaphopod Cadulus sp_1 Large nematodes were also abundant in the benthic community (see Supplement).

\subsection{Macrofauna standing stock and diversity}

The mean number ( \pm standard deviation) of individuals was significantly higher outside $(11598 \pm 432)$ than inside $(7244 \pm 1403)$ the SAC $(p<0.01)$; however the number of species per $\mathrm{m}^{2}$ did not change significantly across the sampling stations ( $83 \pm 11$ inside SAC, $93 \pm 6$ outside the SAC).

The difference in the total macrofaunal community abundance between stations collected outside and within the SAC was mostly driven by significant changes in abundances of the polychaetes $(p<0.05)$, crustaceans $(p<0.01)$ and nematodes $(p<0.05)$ whilst no significant differences were seen for the other taxonomic levels (Fig. 2a). Polychaetes were found to be the most dominant macrofauna collected both within and outwith of the SAC (Fig. 2a). However, the standardised polychaete abundance did not change significantly $(p>0.05)$ when comparing stations outside and within the SAC. This indicates that the proportion of polychaetes collected within and outside the SAC is similar (ranging from 25-40\%; Fig. 2b). The same trend as seen for the polychaetes was found for the nematodes (Fig. 2b). Crustaceans, however, contributed significantly to the community composition outside of the SAC $(p<0.01)$, and this was caused by one dominant species - Haploops setosa (contributing $\sim 220$ to $\sim 335$ individuals per $\mathrm{m}^{2}$ ). By comparison $H$. setosa had a notably lower presence inside the SAC with the number of individuals found ranging from $\sim 16$ to $\sim 32$ individuals $\mathrm{m}^{-2}$. Echinoderms, dominated by the ophiuroid Ophiocten gracilis, were the only taxa which had a significantly higher contribution $(p<0.05)$ to the community composition inside the SAC compared to outside (Fig. 2b). 

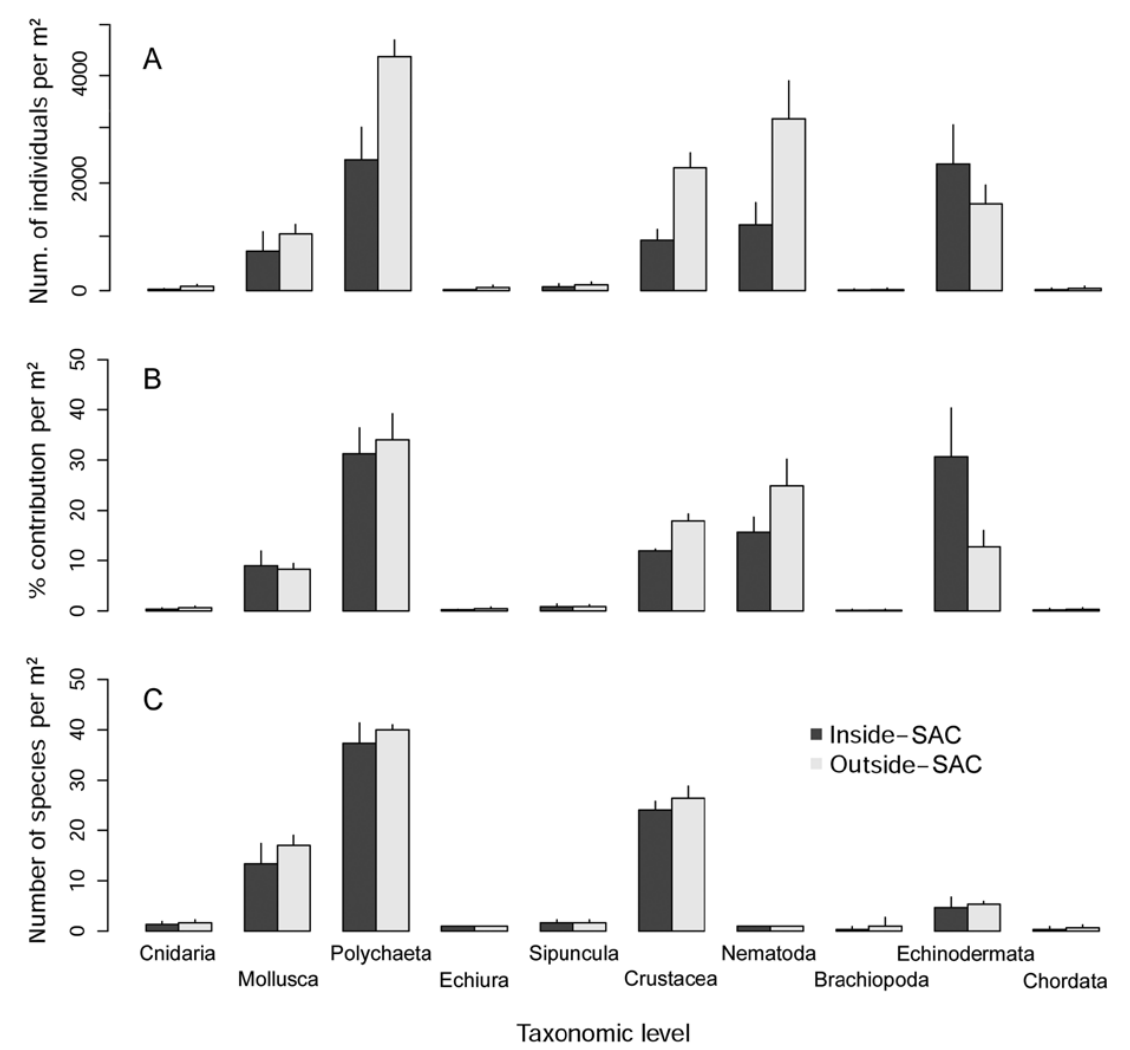

Fig. 2. Number of individuals (A), percentage contribution (B), and species (C) per $\mathrm{m}^{2}$ and per taxonomic level inside and outside the SAC $($ mean $\pm \mathrm{SD})$.

The number of species collected per phylum did not show any significant variation across the samples (Fig. 2c).

Mean values for the other macrofaunal community indices did not show significant differences in terms of diversity (Margalef, Shannon, Pielou and Simpson) (Table 2 and Fig. 3).

\subsection{Macrofaunal community structure and composition}

The cluster analysis and the SIMPROF permutation test showed a high similarity between the samples (Fig. 4). At $57 \%$ similarity, two main groups were identified as having a significantly different internal multivariate structure $(p<0.001)$. These two groups corresponded to samples collected inside and outside the SAC. At $62 \%$ similarity, station 112 was found to be significantly different $(p<0.05)$ from the other sampling sites located inside the SAC (stations 107 and 108). No statistical evidence for any other sub-structure was found (samples connected with a dotted line).

The similarity patterns described were also evident in the MDS showing two distinct major groups (2-D stress: 0) corresponding to inside and outside the $\mathrm{SAC}$ with a similarity of $>57 \%$ (e.g. $60 \%$ in Fig. 5). At a similarity of $>62 \%$ (e.g. $65 \%$ in the Fig. 5), stations 107 and 108 inside the SAC clustered in another sub-group. The average similarity between
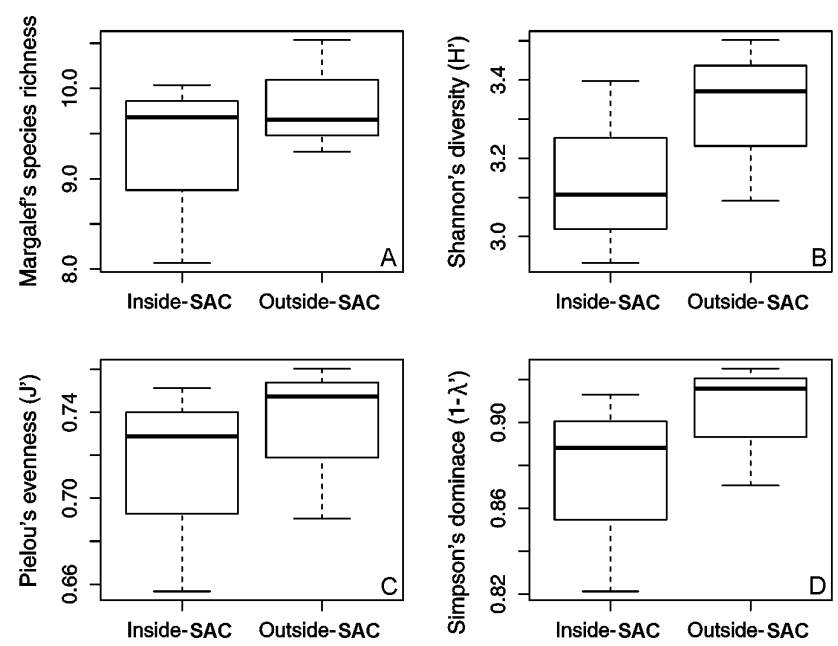

Fig. 3. Box-and-whisker plots of biodiversity indices (A-D) inside and outside the SAC.

samples from outside the SAC (69.6\%) was slightly higher than those from inside the SAC $(64.3 \%)$.

The SIMPER test revealed that the overall dissimilarity $(43 \%)$ between the samples collected inside and outside the SAC was driven by small contributions of most species. Nematoda (3.6\%), the amphipod H. setosa $(2.5 \%)$, 
Table 2. Sediment properties (TOC, TN, median grain size and mud content) and macrofaunal community indices (number of individuals, number of species, Margalef's, Pielou's, Shannon's, Simpson's) at each station collected inside (stations 107, 108 and 112) and outside the SAC (113, 114 and 115).

\begin{tabular}{|c|c|c|c|c|c|c|c|c|c|c|}
\hline \multirow[b]{2}{*}{ Station } & \multicolumn{4}{|c|}{ Sediment properties } & \multicolumn{6}{|c|}{ Macrofaunal community indices } \\
\hline & $\begin{array}{l}\text { TOC } \\
(\%)\end{array}$ & $\begin{array}{l}\mathrm{TN} \\
(\%)\end{array}$ & $\begin{array}{c}\text { Median grain } \\
\text { size } \\
(\mu \mathrm{m})\end{array}$ & $\begin{array}{c}\text { Mud } \\
\text { content } \\
(\%)\end{array}$ & $\begin{array}{c}\text { Number of } \\
\text { individuals } \\
\text { per } \mathrm{m}^{2}\end{array}$ & $\begin{array}{c}\text { Number of } \\
\text { species }\end{array}$ & $\begin{array}{l}\text { Species } \\
\text { richness } \\
\text { (d) }\end{array}$ & $\begin{array}{c}\text { Pielou's } \\
\text { evenness } \\
\left(J^{\prime}\right)\end{array}$ & $\begin{array}{l}\text { Shannon } \\
\left(H^{\prime} \log _{e}\right)\end{array}$ & $\begin{array}{l}\text { Simpson } \\
\left(1-\lambda^{\prime}\right)\end{array}$ \\
\hline 107 & 0.205 & 0.044 & 190.7 & 17.2 & 5858 & 71 & 8.1 & 0.7 & 3.1 & 0.9 \\
\hline 108 & 0.212 & 0.04 & 170.4 & 30.1 & 7213 & 87 & 9.7 & 0.7 & 2.9 & 0.8 \\
\hline 112 & 0.186 & 0.036 & 192.8 & 16.1 & 8662 & 92 & 10 & 0.8 & 3.4 & 0.9 \\
\hline 113 & 0.212 & 0.046 & 139.9 & 16.3 & 11194 & 91 & 9.6 & 0.7 & 3.4 & 0.9 \\
\hline 114 & 0.243 & 0.046 & 153.9 & 16.5 & 12054 & 100 & 10.5 & 0.8 & 3.5 & 0.9 \\
\hline 115 & 0.27 & 0.029 & 158.7 & 13.3 & 11545 & 88 & 9.3 & 0.7 & 3.1 & 0.9 \\
\hline
\end{tabular}

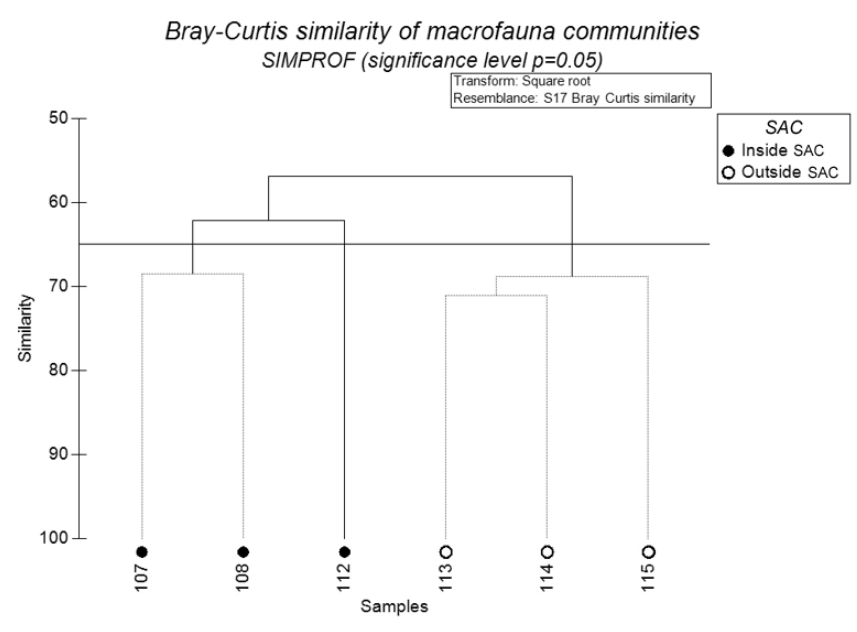

Fig. 4. Cluster analysis and SIMPROF test of macrofaunal species compositions inside $(\bullet)$ and outside (o) the SAC. Dotted lines are connected stations that did not show statistical differences in the multivariate community structure.

the Ostracoda sp_1 $(1.9 \%)$ and the polychaete Aricidea sp_1 $(1.8 \%)$ were the species that contributed most to the overall dissimilarity (cut-off applied at $10 \%$ cumulative dissimilarity). Abundances outside the SAC were up to three, five and 20 times higher than within the SAC for nematodes, the paronid Aricidea sp_1, Ostracoda sp_1, and the amphipod $H$. setosa, respectively.

High abundances found at station 112 (within the SAC) also separated this site from the other two located inside the SAC (107 and 108), resulting in a $38 \%$ dissimilarity. Ostracoda sp_1 (2.1\%), Nematoda (2\%), the polychaete Prionospio sp_1 (2\%) and the scaphopod Pulsellum sp_1 (1.8\%) were the most important species that contributed to this dissimilarity (cut-off applied at $10 \%$ cumulative dissimilarity).

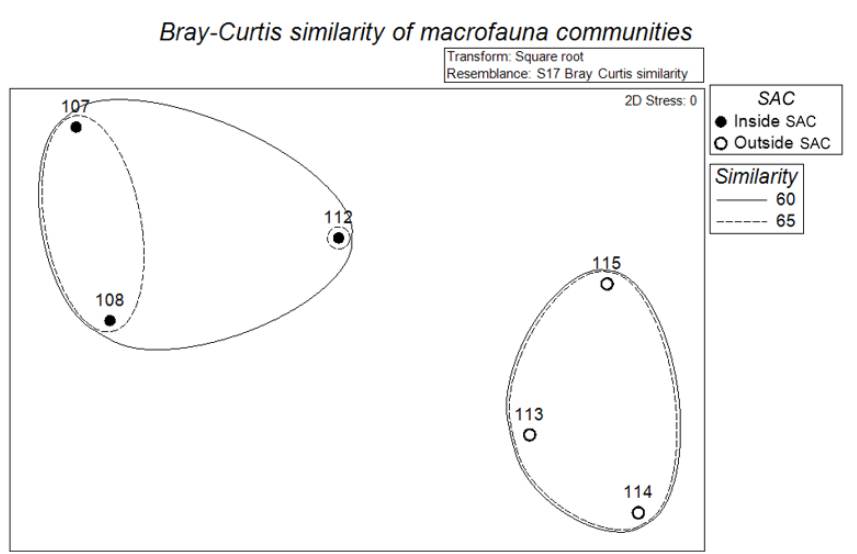

Fig. 5. MDS of macrofaunal species compositions inside $(\bullet)$ and outside (o) the SAC.

\subsection{Sediment properties}

No significant differences were found for TOC $\%, \mathrm{TN} \%$ and percentage of mud content when comparing the stations inside and outside of the SAC. Median grain size at the stations inside the SAC was significantly higher $(p<0.05)$ than stations outwith of the SAC (Table 1).

\section{Discussion}

Since the initial discovery and surveys in 1998-2000, the RRS James Cook cruise 060 in May-June 2011 was the first scientific survey carried out in the Darwin Mounds area. The first high-resolution side-scan sonar and video data collected (1998-2000) illustrated that the area was heavily impacted by bottom trawling activities (Wheeler et al., 2005). This aspect was reinforced by Davies et al. (2007) showing an increase in vessel activity in the area just before the closure was put in place. A significant reduction in trawling intensity has been recorded in the area over the last $11 \mathrm{yr}$. The 
reduction is especially marked in the eastern Darwin Mounds (Huvenne, 2011), the area that was most heavily affected in 2003 (Davies et al., 2007). However some data indicate that some violation of the fisheries closure still occurs in the western Darwin Mounds region (Huvenne, 2011).

Unfortunately, collecting samples in the deep sea is still a challenge, and coring in sandy sediments is often impossible even in shallow water. The relatively coarse sediments at much of the sampling area unfortunately prevented a random sampling design and restricted the number of samples we were able to retrieve. However, investigations of smallscale horizontal macrofauna patterns have been to date very rare particularly in deep waters (Ellingsen, 2002; Budaeva et al., 2008). Moreover, this study offered the opportunity to undertake a preliminary assessment of the potential effect of the first deep water SAC on the macrofaunal community in an area that has already been damaged by trawling and that has subsequently been protected.

In contrast to previous findings (Clark and Rowden, 2009; Kaiser and Spencer, 1996; Duineveld et al., 2007; de Juan et al., 2011), our results did not show an increase in abundance and biodiversity of the benthic community inside the SAC. On the contrary, significantly higher species abundance was found outside the SAC than within. However, there are several abiotic and biotic factors that can determine this difference, such as different geographic areas, different sampling approaches, as well as environmental variables and trophic level interactions that could affect small-scale spatial heterogeneity.

Trawls, epibenthic sledges, Day grabs and box corers were generally used to assess community diversity (Bremner et al., 2003), small- and large-scale spatial heterogeneity in the deep sea (Grassle and Maciolek, 1992; Cosson et al., 1997; Levin et al., 2001; Ellingsen, 2002; Budaeva et al., 2008) and to evaluate the trawling impact on the benthic community in shallow (Kaiser and Spencer, 1996; Queirós et al., 2006; Duineveld et al., 2007; Demestre et al., 2008; de Juan et al., 2011) and deep waters (Clark and Rowden, 2009), whereas in our study a megacorer was used. However it is known that both the Day grab and box corer usually underestimate both faunal abundance and biomass (Bett, 2000). The trawl and epibenthic sledge both generally used a $10 \mathrm{~mm}$ cod-end mesh, or coarser mesh, to assess the epifaunal community. Therefore the fauna collected are species that are generally classed as megafaunal instead of macrofaunal species (Kaiser and Spencer, 1996; Bremner et al., 2003; Demestre et al., 2008; Clark and Rowden, 2009; de Juan et al., 2011).

In our study, the macrofauna were retained on a $250 \mu \mathrm{m}$ sieve mesh. Using a fine mesh sieve is a key factor for deep water infaunal analysis where the specimens tend to be particularly small (Gage et al., 2002; Kaariainen and Bett, 2006; Rex et al., 2006; Ramirez-Llodra et al., 2010). However this makes it more difficult to compare our results with other "macrofaunal" community studies where a coarser mesh (generally $1 \mathrm{~mm}$ ) has generally been used
(Kaiser and Spencer, 1996; Ellingsen, 2002; Jennings et al., 2002; Queirós et al., 2006; Duineveld et al., 2007; Budaeva et al., 2008; de Juan et al., 2011).

Other factors that are important drivers of macrofaunal diversity and abundance are sediment grain size distribution, OM contents and depth (Gage et al., 1995; Gage, 1996; Ellingsen, 2002; Budaeva et al., 2008). The sediment collected in our study was classed as being moderately wellsorted fine sand, confirming the findings of Huvenne et al. (2009). No significant differences were found in terms of sediment percentage of mud and OM contents between stations collected outside and within the Darwin Mounds SAC. Station 108 (within the SAC) was an exception with higher concentration of mud content compared to the other sampling sites, but this attribute did not single out this site in terms of macrofaunal community composition. However, median grain size was found to be significantly lower outside the SAC compared to within, but still in the range of fine sand. This difference could be due to the fact that samples outside the SAC have been collected in a pockmark area characterised by the presence of finer sediments (Huvenne et al., 2009). Our results did not show any differences in biodiversity indices between outside the SAC and within, and none of the macrofaunal species identified here was known as a component of deep cold-seep communities (Levin, 2005). There is no evidence that the pockmark area adjacent to the Darwin Mounds is currently active (Masson et al., 2003); its historical presence however could explain the finer sediment and the higher macrofauna abundances found in the area (Levin, 2005). Other studies showed that the macrofaunal abundances and biomass in the Rockall Trough were also variable with depth (Bett et al., 2001); however the relative variability in abundances that we found between inside and outwith the SAC was five times higher than previously recorded.

Despite the differences in macrofaunal abundances, our results showed high similarity level ( $>57 \%$ ) of the communities across the samples with no differences in terms of biodiversity indices. The level of dissimilarity between all our samples could be determined by the patchy horizontal distribution of the macrobenthic species driven by the small depth gradient (Table 1), and sediment median grain size (Table 2). The level of similarity that we found was higher than other studies (Clark and Rowden, 2009; Narayanaswamy et al., 2005; 2010), but comparable with the findings of Ellingsen (2002) and Budaeva et al. (2008), who looked at spatial patterns at a scale of $\sim 20 \mathrm{~km}$. However, in contrast to these studies where the dissimilarity was determined by horizontal shifts of the dominant species and where the abundances across the samples were very similar, we found that the number of individuals per $\mathrm{m}^{2}$ was significantly higher in the samples collected outside than inside the SAC. Total abundance for both within and outside the SAC ( $\sim 6000$ up to 12400 individuals $\mathrm{m}^{-2}$ ) was higher than the abundances, at comparable depths, found in the Faroe-Shetland Channel 
( $\sim 3000$ individuals $\mathrm{m}^{-2}$; Narayanaswamy et al., 2005), in the north-east Rockall Trough (the comparison has been made with selected sampling stations with similar grain size, OM characteristics and geographical coordinates to our study area: AFEN, 2000) and in the North Sea at the same latitude ( 6000 individuals $\mathrm{m}^{-2}$ ) (Basford et al., 1990); however a coarser mesh size was used in these studies. When the same size of mesh (i.e. $250 \mu \mathrm{m}$ ) was used, our total abundance was of the same order of magnitude as that found in the Rockall Trough ( $\sim 10000$ individuals per $\mathrm{m}^{2}$; Gage et al., 2002), but our polychaete abundance (up to 4650 individuals $\mathrm{m}^{-2}$ ) was still higher than the findings in the Faroe-Shetland Channel (Narayanaswamy, 2000). Biodiversity values, however, were comparable with those at a similar depth in the Faroe-Shetland Channel (Narayanaswamy et al., 2005, 2010), higher than the findings in the north-east Rockall Trough (AFEN, 2000), but lower compared to macrofauna collected in the Rockall Trough by Gage et al. (2002).

Long-term effect of fishing generally determined changes in larger and usually less abundant species, and significant differences across sampling sites are more difficult to assess in a multivariate analysis that, when using strong data transformations, tends to down-weight the presence of common larger species with low abundances (Duineveld et al., 2007). Because of the high abundances of small species in our samples, we used the square root transformation instead of stronger ones. The same results were obtained using no transformation of the data. When strong data transformations were applied (e.g. fourth root, logarithm or presence/absence), the similarity across the samples increased even more due to the high abundances of small nematodes and polychaetes in our samples.

The trawling activity can damage or even completely destroy fragile specimens, which in turn quickly attract infaunal detritivore species (Kaiser and Spencer, 1996). Kaiser et al. (2000) also underlined the prevalence of opportunistic species in areas disturbed by fishing. These aspects could explain why higher abundances of nematodes and the generally smaller opportunistic polychaete families, such as the paraonids, spionids, and capitellids, were observed in our study outside the SAC and hence their importance in structuring the macrofaunal community.

However, because the effect of fishing has a greater impact on larger species, i.e. the removal of the megafauna and demersal fish predators by fishing gears, the significant difference of species abundances observed inside and outside the SAC could represent an ecological response to the reduced predation pressure on macro- and meiofaunal species. This may explain the high abundances of large specimens (up to $100 \mathrm{~mm}$ ) and is hence more desirable to megafauna and demersal fish species, of the amphipod Haploops setosa on fished sites. H. setosa was also identified by the SIMPER test as one of the main species contributing to the dissimilarity between the samples collected outside and within the SAC, with the community outside the SAC being dominated by this species. The specimens collected in this study were found living in pouch-like tubes as described for the first time by Shields and Hughes (2009). Echinoderms, mostly consisting of Ophiocten gracilis species, were the only phylum that showed a higher percentage contribution of abundances inside the SAC sites compared to outside (Fig. 2b) indicating that this species may be particularly vulnerable to damage or disturbance by beam-trawling. However this aspect could also reflect the patchy distribution pattern typical of this species (Piepenburg and von Juterzenka, 1994). To shed light on underlying mechanisms of benthic community responses to the impact of demersal fisheries in terms of biodiversity and abundances, it is therefore important that the size spectra ecological concept (size-abundance relationships) (Kaariainen and Bett, 2006) and the predator-prey interactions within benthic communities are also considered.

None of the community diversity indices investigated (Margalef's species richness, Pielou's evenness, Shannon's diversity and Simpson's dominance) showed significant differences across the sites, similar to studies analysing the same level of macrofaunal spatial heterogeneity, but different from those assessing the effect of marine protected areas on faunal communities (Clark and Rowden, 2009; Kaiser and Spencer, 1996; Duineveld et al., 2007; de Juan et al., 2011). One reason could also be the proximity to the SAC western side boundary of the stations within the SAC where some violation of the fisheries closure still seems to occur $(\mathrm{Hu}-$ venne, 2011). However, mean values of all biodiversity indices were higher outside the SAC stations. Increasing diversity in fished areas may be also an ecosystem response to intermediate levels of disturbance following the "intermediate disturbance hypothesis" (Connell, 1978) and the "dynamic equilibrium theory" (Huston, 1979) where competitive exclusion was impeded, promoting co-existence in potentially competing species.

The closure of the Darwin Mounds to bottom trawling seems to be fairly well respected, with a reduction in trawl marks within the SAC area. However, the Darwin Mounds still appear to be covered in mainly dead coral, especially the region towards the east, and overall there was little evidence of recovery (Huvenne, 2011). The time necessary for a complete recovery of an impacted ecosystem is variable in relation to the impact. For example, seven years after impact from mining, even in the low resilient abyssal plain benthic ecosystem, all benthic size classes (mega-, macro- and meiofauna) were back to near their initial abundance and diversity values; however in some cases the faunal composition of the size classes could remain permanently altered (Thiel, 2003). Compared to the mining impact, which affects all the faunal size classes, trawling activity has a greater effect on the megafaunal species. This selectivity could determine community shifts that also affect the recovery time. In our results, the multivariate analysis showed a higher degree of dissimilarity between the samples collected within the SAC than outside. Increased variability among samples possibly 
indicates communities from a disturbed environment (Clark and Rowden, 2009); however it can also indicate changes due to the ecosystem recovering.

Horizontal "small-scale" spatial distribution patterns of macrofauna, the impact of trawling on these communities and the role of marine protected areas for their preservation are concepts that to date are not well understood, particularly in deep sea sediments. These aspects are gaining even more importance considering the overarching goal of the European integrated maritime policy, to achieve a "Good Environmental Status" by 2020 across Europe's offshore Special Areas of Conservation (SAC) and Marine Protected Area (MPA) (JNCC website: http://jncc.defra.gov.uk/). As this cruise in 2011 was the first scientific survey carried out in the Darwin Mounds area since the SAC establishment, the stations that we sampled could be used as baseline information for future monitoring assessment.

\section{Supplementary material related to this article is

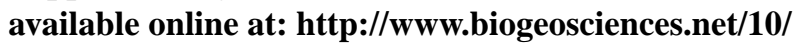 3705/2013/bg-10-3705-2013-supplement.pdf.}

Acknowledgements. The research leading to these results has received funding from the European Community's Seventh Framework Programme (FP7/2007-2013) under the HERMIONE project, grant agreement no. 226354. Our thanks go to our colleagues Veerle Huvenne and Brian Bett (NOC, Southampton), who contributed to various aspects of the discussion and to Niels Jobstvogt (Oceanlab) for his help in collecting the samples. Evina Gontikaki was funded by the MASTS pooling initiative (The Marine Alliance for Science and Technology for Scotland, grant reference HR09011).

Edited by: R. Serrão Santos

\section{References}

AFEN: Environmental Surveys of the Seafloor of the UK Atlantic Margin. Atlantic Frontier Environmental Network [CD-ROM], ISBN 09538399-0-7, 2000.

Balata D., Piazzi L., and Benedetti-Cecchi L: Sediment disturbance and loss of beta diversity on sub tidal rocky reefs, Ecology, 88, 2455-2461, 2007.

Basford, D., Eleftheriou, A., and Raffaelli, D.: The infauna and epifauna of the Northern North Sea, Neth. J. Sea Res., 25, 165-173, 1990.

Bett, B. J.: Benthic ecology of Faeroe-Shetland Channel, Section 4.3.1 in Environmental Survey of the Seafloor of the UK Atlantic Margin. Atlantic Frontier Environmental Network [CD-ROM], ISBN 09538399-0-7, 2000.

Bett, B. J.: UK Atlantic Margin Environmental Survey: introduction and overview of bathyal benthic ecology, Cont. Shelf Res., 21, 917-956, 2001.
Bett, B. J., Malzone, M. G., Narayanaswamy, B. E., and Wigham, B. D.: Temporal variability in phytodetritus and megabenthic activity at the seabed in the deep Northeast Atlantic, Prog. Oceanogr., 50, 349-368, 2001.

Bremner, J., Rogers, S. I., and Frid, C. L. J.: Assessing functional diversity in marine benthic ecosystems: a comparison of approaches, Mar. Ecol.-Prog. Ser., 254, 11-25, 2003.

Budaeva, N. E., Mokievsky, V. O., Soltwedel, T., and Gebruk, A. V.: Horizontal distribution patterns in Arctic deep-sea macrobenthic communities, Deep-Sea Res. Pt. I, 55, 1167-1178, 2008.

Clarke, K. R. and Gorley, R. N.: PRIMER v6: User manual/Tutorial, PRIMER-E: Plymouth, 2006.

Clark, M. R. and Rowden, A. A.: Effect of deepwater trawling on the macro invertebrate assemblages of seamounts on the Chatham Rise, New Zealand, Deep Sea Res. Pt. I, 56, 1540 1554, 2009.

Clarke, K. R. and Warwick, R. M.: Change in marine communities: an approach to statistical analysis and interpretation, 2nd Edn., PRIMER-E, Plymouth, 2001.

Connell, J. H.: Diversity in tropical rain forest and coral reefs, Science, 199, 1302-1310, 1978.

Cosson, N., Sibuet, M., and Galeron, J.: Community structure and spatial heterogeneity of the deep-sea macrofauna at three contrasting stations in the tropical northeast Atlantic, Deep-Sea Res. Pt. I, 44, 347-269, 1997.

Danovaro, R., Dell'Anno, A., Corinaldesi, C., Magagnini, M., Noble, R., Tamburini, C., and Weinbauer, M.: Major viral impact on the functioning of benthic deep-sea ecosystems, Nature, 454, 1084-1087, 2008.

Davies, A. J., Roberts, J. M., and Hall-Spencer, J.: Preserving deepsea natural heritage: Emerging issues in offshore conservation and management, Biol. Conserv., 138, 299-312, 2007.

de Juan, S., Demestre, M., and Sanchez, P.: Exploring the degree of trawling disturbance by the analysis of benthic communities ranging from a heavily exploited fishing ground to an undisturbed area in the NW Mediterranean, Scienza Marina, 73, 507516, 2011.

de Juan, S., Thrush, S. F., and Demestre, M.: Functional changes as indicators of trawling disturbance on a benthic community located in a fishing ground (NW Mediterranean Sea), Mar. Ecol.Prog. Ser., 334, 117-129, 2007.

Demestre, M., de Juan S., Sartor, P., and Ligas, A.: Seasonal closures as a measure of trawling effort control in two Mediterranean trawling grounds: Effects on epibenthic communities, Mar. Pollut. Bull., 56, 1765-1773, 2008.

Duineveld, G. C. A., Bergman, M. J. N., and Lavaleye, M. S. S.: Effects of an area closed to fisheries on the composition of the benthic fauna in the southern North Sea, ICES J. Mar. Sci., 64, 899-908, 2007.

Ellingsen K. E.: Soft-sediment benthic biodiversity on the continental shelf in relation to environmental variability, Mar. Ecol.-Prog. Ser., 232, 15-27, 2002.

European Council, The President J. Walsh: Council Regulation (EEC) No. 602/2004 of 22 March 2004. The effects of trawling in an area north west of Scotland, Official Journal L97, 30-31, 2004.

Gage, J. D.: Structure of the abyssal macrobenthic community in the Rockall Trough, in: Biology of Benthic Organisms, edited by: Keegan, B. F., Ceidigh, P. O., Boaden, P. J. S., Pergamon, 
Oxford, 247-260, 1975.

Gage J. D.: Why are there so many species in the deep-sea sediments?, J. Exp. Mar. Biol. Ecol., 200, 257-286, 1996.

Gage J. D., Lamont P. A., and Tyler P. A.: Deep-sea macrobenthic community structure at contrasting sites off Portugal, preliminary results: 1 Introduction and diversity comparisons, Int. Rev. Gesamt. Hydrobiol., 80, 235-250, 1995.

Gage, J. D., Hughes, D. J., and Gonzales Vecino, J. L.: Sieve size influence in estimating biomass, abundance and diversity in samples of the deep-sea macrobenthos, Mar. Ecol.-Prog. Ser., 225, 97-107, 2002.

Grassle, F. J. and Maciolek, N. J.: Deep-sea species richness: regional and local diversity estimates from quantitative bottom samples, Am. Nat., 139, 313-341, 1992.

Gubbay, S., Backer, C. M., and Bett, B. J.: The Darwin Mounds and the Dogger Bank. Case of study of management of two potential "Special Areas of Conservation" in the offshore environment, Report to the World Wide Fund for Nature, Southampton Oceanography Centre, 16 pp., 2002.

Hunter, W. R., Jamieson, A., Huvenne, V. A. I., and Witte, U.: Sediment community responses to marine vs. terrigenous organic matter in a submarine canyon, Biogeosciences, 10, 67-80, doi:10.5194/bg-10-67-2013, 2013.

Huston, M.: A general hypothesis of species diversity, Am. Nat., 113, 81-101, 1979.

Huvenne, V. A. I.: Benthic habitats and the impact of human activities in Rockall Trough, on Rockall Bank and in Hatton Basin. National Oceanography Centre, Cruise Report No. 04, RRS James Cook Cruise 60, 133 pp., 2011.

Huvenne, V. A. I., Masson, D. G., and Wheeler, A. J.: Sediment dynamics of a sandy contourite: the sedimentary context of the Darwin cold-water coral mounds, Northern Rockall Trough, Int. J. Earth Sci., 98, 865-884, 2009.

Jennings, S., Nicholson, M. D., Dinmore, T. A., and Lancaster, J. E.: Effects of chronic trawling disturbance on the production of infaunal communities, Mar. Ecol.-Prog. Ser., 243, 251-260, 2002.

JNCC website (Joint Nature Conservation Committee): EU Marine Strategy Framework Directive, http://jncc.defra.gov.uk/ page-5193, last access: 25 October 2012.

Kaariainen, J. I. and Bett, B. J.: Evidence for the benthic body size miniaturization in the deep sea, J. Mar. Biol. Assoc. UK, 86, 1339-1345, 2006.

Kaiser, M. J. and Spencer, B. E.: The effects of beam-trawl disturbance on infaunal communities in different habitats, J. Anim. Ecol., 65, 348-358, 1996.

Kaiser, M. J., Spence. F. E., and Hart, P. J. B.: Fishing-gear restrictions and conservation of benthic habitat complexity, Conserv. Biol., 14, 1512-1525, 2000.

Kendall, M. A. and Widdicombe, S.: Small scale patterns in the structure of macrofaunal assemblages of shallow soft sediments, J. Exp. Mar. Biol. Ecol., 237, 127-140, 1999.

Levin, L. A.: Ecology of cold seep sediments: interactions of fauna with flow, chemistry, and microbes, Oceanogr. Mar. Biol., 43, 146, 2005.

Levin, L. A. and Dayton, P. K.: Ecological theory and continental margins: Where shallow meets deep, Trends Ecol. Evol., 24, 606-617, 2009.

Levin, L. A., Blair, N. E., Martin, C. M., DeMaster, D. J., Plaia, G., and Thomas, C. J.: Macrofaunal processing of phytodetritus at two sites on the Carolina margin: in situ experiments using ${ }^{13}$ C-labeled diatoms, Mar. Ecol.-Prog. Ser., 182, 37-54, 1999.

Levin, L. A., Sibuet, M., Gooday, A. J., Smith, C. R., and Vanreusel, A.: The roles of habitat heterogeneity in generating and maintaining biodiversity on continental margins: an introduction, Mar. Ecol., 31, 1-5, 2010.

Martín, J., Puig, P., Palanques, A., Masqué, P., and García-Orellana, J.: Effect of commercial trawling on the deep sedimentation in a Mediterranean submarine canyon. Mar. Geol., 252, 150-155, 2008.

Masson, D. G., Bett, B. J., Billett, D. S. M., Jacobs, C. L., Wheeler, A. J., and Wynn, R. B.: The origin of deep-water, coral-topped mounds in the northern Rockall Trough, Northeast Atlantic, Mar. Geol., 194, 159-180, 2003.

Middelburg, J. J., Soetaert, K., and Herman, P. M. J.: Empirical relationships for use in global diagenetic models, Deep-Sea Res. Pt. I, 44, 327-344, 1997.

Narayanaswamy, B. E.: Macrobenthic Ecology of the West Shetland Slope, PhD University of Southampton, p. 214, 2000.

Narayanaswamy, B. E., Bett, B. J., and Gage, J. D.: Ecology of bathyal polychaete fauna at an Arctic-Atlantic boundary (FaroeShetland Channel, North-east Atlantic), Mar. Biol. Res., 1, 2032, 2005.

Narayanaswamy, B. E., Bett, B. J., and Hughes, D. J.: Deep-water macrofauna diversity in the Faroe-Shetland region (NE Atlantic): a margin subject to an unusual thermal regime, Mar. Ecol., 31, 237-246, 2010.

Piepenburg, D. and von Juterzenka, K.: Abundance, biomass and spatial distribution pattern of brittle stars (Echinodermata: Ophiuroldea) on the Kolbeinsey Ridge north of Iceland, Polar. Biol., 14, 185-194, 1994.

Puig, P., Canals, M., Company, J. B., Martín, J., Amblas, D., Lastras, G., and Palanques, A.: Ploughing the deep sea floor, Nature, 489, 286-289, 2012.

Queirós, A. M., Hiddink, J. G., Kaiser, M. J., and Hinz, H.: Effects of chronic bottom trawling disturbance on benthic biomass, production and size spectra in different habitats, J. Exp. Mar. Biol. Ecol., 335, 91-103, 2006.

Ramirez-Llodra, E., Brandt, A., Danovaro, R., De Mol, B., Escobar, E., German, C. R., Levin, L. A., Martinez Arbizu, P., Menot, L., Buhl-Mortensen, P., Narayanaswamy, B. E., Smith, C. R., Tittensor, D. P., Tyler, P. A., Vanreusel, A., and Vecchione, M.: Deep, diverse and definitely different: unique attributes of the world's largest ecosystem, Biogeosciences, 7, 2851-2899, doi:10.5194/bg-7-2851-2010, 2010.

Rex, M. A., Etter, R. J., Morris, J. S., Crouse, J., McClain, C. R., Johnson, N. A., Stuart, C. T., Deming, J. W., Thies, R., and Avery R.: Global bathymetric patterns of standing stock and body size in the deep-sea bentho, Mar. Ecol.-Prog. Ser., 317, 1-8, 2006.

Shields, M. A. and Hughes, D. J.: Large-scale variation in macrofaunal communities along the eastern Nordic Seas continental margin: A comparison of four stations with contrasting food supply, Prog. Oceanogr., 82, 125-136, 2009.

Stuart, C. T., Rex, M. A., and Etter, R. J.: Large-scale spatial and temporal patterns of deep-sea benthic species diversity, in: Ecosystems of the World 28, Ecosystems of the Deep Oceans, edited by: Tyler, P. A., Elsevier, Amsterdam, Boston, London, New York, Oxford, Paris, San Diego, San Francisco, Singapore, Sydney, Tokyo, 295-311, 2003. 
Thiel, H.: Anthropogenic impacts on the deep sea, in: Ecosystems of the World: The Deep Sea, edited by: Tyler, P. A., Amsterdam, the Netherlands, Elsevier, 427-471, 2003.

Van Gaever, S., Vanreusel, A., Hughes, J. A., Bett, B., and Kiriakoulakis, K.: The macro- and micro-scale patchiness of meiobenthos associated with the Darwin Mounds (north-east Atlantic), J. Mar. Biol. Assoc. UK, 84, 547-556, 2004.

Wheeler, A. J., Bett, B. J., Billett, D. S. M., Masson, D. G., and Mayor, D.: The impact of demersal trawling on Northeast Atlantic deepwater coral habitats: The case of the Darwin Mounds, United Kingdom. In: Benthic Habitats and the Effects of Fishing, edited by: Barnes, P. W., Thomas, J. P., Am. Fish. S., Bethesda, M. D., 807-817, 2005.
Whittaker, R. H.: Vegetation of the Siskiyou Mountains, Oregon and California, Ecol. Monogr., 30, 279-338, 1960.

Witte, U., Aberle, N., Sand, M., and Wenzhöfer, F.: Rapid response of a deep-sea benthic community to POM enrichment: an in situ experimental study, Mar. Ecol.-Prog. Ser., 25, 1, 27-36, 2003.

Wlodarska-Kowalczuk, M., Kendall, M. A., Weslawski, J. M., Klages, M., and Soltwedel, T.: Depth gradients of benthic standing stock and diversity on the continental margin at a high latitude ice-free site (off West Spitsbergen, 791N), Deep-Sea Res. Pt. I, 51, 1903-1914, 2004. 